\title{
PENGGUNAAN SOFTWARE MATRIX LABORATORY (MATLAB) DALAM PEMBELAJARAN ALJABAR LINIER
}

\author{
Budi Cahyono \\ DosenJurusan Tadris Matematika FITK IAIN Walsiongo
}

\begin{abstract}
Abstrak
Perkembangan dan kehadiran teknologi komputer telah memberikan kemudahan berbagai pihak untuk menggunakannya dalam bidang kehidupan, termasuk pendidikan, sebagai sarana penunjang pendidikan. Komputer semakin memberikan manfaat yang besar di dunia pendidikan, khususnya dalam proses pembelajaran. Terdapat ratusan bahkan ribuan program aplikasi komputer atau perangkat lunak yang dapat dimanfaatkan untuk pembelajaran matematika, khususnya Aljabar Linier. Salah satu perangkat lunak bantu yang dapat digunakan dalam pembelajaran Aljabar linier yaitu Matrix Laboratory (MATLAB). Program ini dapat dimanfaatkan untuk meningkatkan kecepatan, dan keakuratan dalam berbagai perhitungan dalam pembelajaran aljabar linier sehingga waktu yang diperlukan untuk mengerjakan lebih efisien dan hasil yang diperoleh lebih akurat dibandingkan dengan perhitungan yang dilakukan secara manual, selain itu juga dapat memvisualisasikan grafik dalam bentuk 2 dimensi maupun 3 dimensi, misalnya dalam penyelesaian Sistem Persamaan Linier sehingga diharapkan dapat meningkatkan pemahaman terhadap materi yang diberikan.
\end{abstract}

Kata Kunci : Aljabar Linier, Matrix Laboratory (MATLAB) 


\section{PENDAHULUAN}

Perkembangan dan kehadiran teknologi komputer dewasa ini telah memberikan kemudahan berbagai pihak untuk menggunakannya dalam bidang kehidupan, termasuk pendidikan, sebagai sarana penunjang pendidikan. Hal ini dikarenakan dengan menggunakan komputer dapat mempertinggi efisiensi suatu pekerjaan yang disebabkan adanya kelebihan/manfaat dari komputer. Kelebihan tersebut diantaranya adalah dapat mengerjakan pekerjaan dengan cepat dan tepat, dapat menyimpan data maupun memanggilnya kembali dan dapat memproses data/informasi dalam cakupan besar. Bahkan dengan adanya perkembangan teknologi khususnya dalam program-program aplikasinya, saat ini komputer semakin memberikan manfaat yang besar di dunia pendidikan, khususnya dalam proses pembelajaran.

Terdapat ratusan bahkan ribuan program aplikasi atau perangkat lunak yang dapat dimanfaatkan untuk pembelajaran matematika, yang terpenting adalah bahwa pengajar harus memiliki pengetahuan/wawasan dan keterampilan menggunakan berbagai perangkat lunak tersebut serta mampu memilih perangkat lunak yang sesuai untuk mendukung pembelajaran topik tertentu, dalam hal ini topik aljabar linier. Salah satu perangkat lunak bantu yang dapat digunakan dalam pembelajaran Aljabar linier yaitu Matrix Laboratory (MATLAB). Program ini dapat dimanfaatkan untuk meningkatkan kecepatan, dan keakuratan dalam berbagai perhitungan dalam materi aljabar linier sehingga waktu yang diperlukan untuk mengerjakan lebih efisien dan hasil yang diperoleh lebih akurat dibandingkan dengan perhitungan yang dilakukan secara manual, juga dapat memvisualisasikan grafik dalam bentuk 2 dimensi maupun 3 dimensi, yang tentu saja sulit jika digambar secara manual, sehingga diharapkan dapat meningkatkan pemahaman terhadap materi yang dipelajari.

\section{POLA PEMBELAJARAN MATEMATIKA}

Matematika memiliki karekteristik yang unik dengan 
berbeda dengan mata pelajaran lain. Karakteristik inilah maka penyusunan bahan ajar matematikapun memiliki pola tersendiri. Obyek dasar mata pelajaran matematika adalah obyek yang abstrak, karenanya bahan ajarnya dituntut sebisa mungkin untuk menvisualisasikan obyek yang abstrak tersebut, dengan visualisasi ini obyek yang abstrak akan dapat memperoleh perwakilannya atau gambaran yang tepat dan mudah dipahami. Menurut Thohari, bahwa Obyek matematika tersebut meliputi ; fakta, konsep, definisi, operasi, prinsip dan skill yang diuraiakan sebagai berikut.

\section{Fakta}

Fakta berupa konvensi-konvensi atau kesepakatan yang disetujui bersama sebagai kebenaran, yang diungkap dengan simbol tertentu. Misalnya simbol "3" dipahami sebagai bilangan "tiga", simbol "2+4=" dipahami sebagai "dua tambah empat dan bisa dinyatakan dalam hasil tunggal sebuah operasi penjumlahan yaitu bilangan "5". Simbol "//" bermakna "sejajar", simbol $(a, b)$ sebagai pasangan berurutan atau dalam kalkulus sebagai interval terbuka. Jika materi Fakta maka sajikan bahan ajar presentasi atau referensi yang menampilkan konsep yang dimaksud seperti: macam macam bilangan, jenis segitiga, Janis-jenis binatang memamah biak, tanaman berbiji tunggal.

\section{Konsep}

Konsep adalah ide abstrak yang dapat digunakan untuk mengolongkan sejumlah obyek. Apakah obyek tertentu merupakan contoh konsep ataukah bukan konsep.Jenis bahan ajarnya bisa presentasi atau interaktif belajar mandir dengan menampilkan materi yang dimaksud dengan memberikan contoh dan bukan contoh secara interaktif untuyk menguji pemahaman konsep siswa. Seperti konsep "Segitiga" macam macam segitiga, "fungsi" dan berbagai jenis fungsi, "variabel”, "konstanta”, "matriks", "vektor", "group", dan "ruang metrik"

\section{Definisi}

Definisi adalah ungkapan yang membatasi suatu konsep 
"Trapesium adalah segiempat yang sepasang sisinya sejajar" (definisi analitik). "Segiempat yang terjadi jika sebuah segitiga dipotong oleh sebuah garis yg sejajar salah satu sisinya adl trapesium" (definisi generik). Apakah kompetensi dasar berupa mengemukakan suatu definisi, menjelaskan, mengklarifikasikan beberapa contoh sesuai dengan definisi? Bujur sangkar ialah empat persegi panjang yang ke empat sisinya sama panjang. Usahakan sebelum definisi itu ungkap dahului dengan kegiatamnkegiatan yang nantinya siswa mempu membuat generalisi dan definisi itu dengan metode penemuan terbimbing. Bahan Ajar yang harus dipersiapkan jelas adalah tipe interaktifbelajar mandiri atau presentasi yang mengedepankan contoh-contoh intyeraktif untuk menguji definisi, atau juga aktifitas-aktifitas yang membawa siwa pada pross pendifinisian konsep.

\section{Operasi}

Operasi adalah suatu relasi khusus, yang menghubungkan dua anggota himpunan atau lebih dengan aturan tertentu untuk memperoleh elemen tunggal dari satu atau lebih elemen yang diketahui Operasi unair, operasi biner pengerjaan hitung, pengerjaan aljabar, dan pengerjaan matematika seperti "penjumlahan", "perkalian", "gabungan", "irisan" "komplemen" dst. Bahan ajar yang tepat adalah presentasi dan Interaktif, Dimana pola penekanan adalah pada aktifitas siswa dalam penerapan prinsip prinsip oprasi agar lebih berkembang, dan menemukan sifat-sifat oprasi misalkan tertutup atau terbuka, dimana kegiatan dibuat sedemikian hingga menggiring siswa menemukan hal-halbaru dalam konsep oprasi. Disamping itu latihan interaktif itu juga diharapkan mampu melatih kecepatan dalam menyelesaiakn suatu oprasi.

\section{Prinsip dan skill}

Prinsip dan skill merupakan obyek matematika yang kompleks. Prinsip dapat terdiri dari beberapa fakta, beberapa konsep yang dikaitkan oleh suatu relasi/operasi. Prinsip adalah hubungan antara berbagai obyek dasar matematika. Prinsip dapat 
berupa aksioma, teorema, sifat. Skill adalah prosedur atau kumpulan aturan-aturan yang digunakan untuk menyelesaikan soal matematika. Contoh penyelesaian persamaan dengan "melengkapkan kuadrat sempurna". Penyelesaian system persamaan denga prinsip "Eliminasi". Ini berarti kompetensi dasar yang berupa menjelasakan langkah-langkah mengerjakan sesuatu sesuai dengan produser tertentu, maka bahan ajar yang paling tepat adalah presentasi dan media interaktif, dimana penekanan bahan ajar pada penguasaan skill pengerjaan, pendalam dan pemahaman akan konsep perlu penekanan, maka bahan ajar yang disusun haruslah berfokus pada latihan dan kegiatan untuk melakukan aktifitas. Seperti ketrampilan melukis macammacam segitiga, kemampuan menyelesaikan model matematika dengan berbagai skill pendekatan penyelesaian.

Mengingat obyek-obyek matematika di atas, maka dalam proses pembelajaran berbantuan computer perlu dipahami dengan baik bagaimana karaktristik setiap software yang akan digunakan, termasuk Matrix Labolatory (MATLAB) sehingga pembelajaran matematika akan lebih interaktif dan banyak menggunakan alat peraga untuk memvisualisasikan ide matematika yang abstrak.

\section{MATLAB SEBAGAI MEDIA PEMBELAJARAN MATEMA- TIKA}

\section{Pengantar tentang MATLAB}

MATLAB (Matrix Laboratory) adalah suatu program untuk analisis dan komputasi numerik dan merupakan suatu bahasa pemrograman matematika lanjutan yang dibentuk dengan dasar pemikiran menggunakan sifat dan bentuk matriks. Pada awalnya, program ini merupakan interface untuk koleksi rutin-rutin numeric dari proyek LINPACK dan EISPACK, dan dikembangkan menggunkan bahasa FORTRAN namun sekarang merupakan produk komersial dari perusahaan Mathworks, Inc.yang dalam perkembangan selanjutnya dikembangkan menggunakan bahasa $\mathrm{C}++$ dan assembler (utamanya untuk fungsi-fungsi dasar MATLAB). 
MATLAB telah berkembang menjadi sebuah environment pemrograman yang canggih yang berisi fungsi-fungsi built-in untuk melakukan tugas pengolahan sinyal, aljabar linier, dan kalkulasi matematis lainnya. MATLAB juga berisi toolbox yang berisi fungsi-fungsi tambahan untuk aplikasi khusus . MATLAB bersifat extensible, dalam arti bahwa seorang pengguna dapat menulis fungsi baru untuk ditambahkan pada library ketika fungsi-fungsi built-in yang tersedia tidak dapat melakukan tugas tertentu. Kemampuan pemrograman yang dibutuhkan tidak terlalu sulit bila Anda telah memiliki pengalaman dalam pemrograman bahasa lain seperti $\mathrm{C}++$, PASCAL, atau FORTRAN.

MATLAB merupakan merk software yang dikembangkan oleh Mathworks.Inc.(lihat http://www.mathworks.com) merupakan software yang paling efisien untuk perhitungan numeric berbasis matriks. Dengan demikian jika di dalam perhitungan kita dapat menformulasikan masalah ke dalam format matriks maka MATLAB merupakan software terbaik untuk penyelesaian numericnya. MATLAB yang merupakan bahasa pemrograman tingkat tinggi berbasis pada matriks sering digunakan untuk teknik komputasi numerik, untuk menyelesaikan masalah-masalah yang melibatkan operasi matematika elemen, matrik, optimasi, aproksimasi dan lain-lain. Sehingga Matlab banyak digunakan pada : ( 1 ) Matematika dan Komputansi, (2) Pengembangan dan Algoritma, (3) Pemrograman modeling, simulasi, dan pembuatan prototype, (4) Analisa Data, eksplorasi dan visualisasi, (5) Analisis numerik dan statistic, dan (6) Pengembangan aplikasi teknik.

\section{Lingkungan Kerja Matlab}

\subsection{Window-window pada MATLAB}

Ada beberapa macam window yang tersedia dalam MATLAB, yang dapat dijelaskan sebagai berikut:

\section{a. Command window/editor}

MATLAB Command window/editor merupakan window yang dibuka pertama kali setiap kali MATLAB dijalankan pada window di atas dapat dilakukan akses- 
akses ke command MATLAB dengan cara mengetikkan barisan-barisan ekpresi MATLAB, seperti mengakses help window dan lain-lainnya. Jika perintah-perintah yang sudah diketikkan dan hasil yang ditampilkan pada layar command window akan disimpan maka dapat dilakukan dengan menggunkan command diary. Command windows juga digunakan untuk memanggil tool Matlab seperti editor, debugger atau fungsi. Command Window adalah tempat untuk menjalankan fungsi, mendeklarasikan variable, menjalankan proses-proses, serta melihat isi variable.

\section{b. Current Directory}

Window ini menampilkan isi dari direktori kerja saat menggunakan matlab. Kita dapat mengganti direktori ini sesuai dengan tempat direktori kerja yang diinginkan. Default dari alamat direktori berada dalam folder works tempat program files Matlab berada.

\section{c. Command History}

Window ini berfungsi untuk menyimpan perintahperintah apa saja yang sebelumnya dilakukan oleh pengguna terhadap matlab.

\section{d. Workspace}

Workspace berfungsi untuk menampilkan seluruh variabel-variabel yang sedang aktif pada saat pemakaian matlab. Apabila variabel berupa data matriks berukuran besar maka user dapat melihat isi dari seluruh data dengan melakukan double klik pada variabel tersebut. Matlab secara otomatis akan menampilkan window "array editor" yang berisikan data pada setiap variabel yang dipilih user.

\subsection{Getting Help}

Matlab menyediakan fungsi help yang tidak berisikan 
tutorial lengkap mengenai Matlab dan segala keunggulannya. User dapat menjalankan fungsi ini dengan menekan tombol pada toolbar atau menulis perintah 'helpwin' pada command window. Matlab juga menyediakan fungsi demos yang berisikan video tutorial matlab serta contoh-contoh program yang bias dibuat dengan MATLAB.

\subsection{Interupting dan Terminating dalam Matlab}

Untuk menghentikan proses yang sedang berjalan pada matlab dapat dilakukan dengan menekan tombol Ctrl-C. Sedangkan untuk keluar dari matlab dapat dilakukan dengan menuliskan perintah exit atau quit pada comamnd window atau dengan menekan menu exit pada bagian menu file dari menu bar.

\section{Variabel Pada Matlab}

Matlab hanya memiliki dua jenis tipe data yaitu Numeric dan String. Dalam matlab setiap variabel akan disimpan dalam bentuk matrik. User dapat langsung menuliskan variabel baru tanpa harus mendeklarasikannya terlebih dahulu pada command window. Contoh pembuatan variabel pada matlab:

$$
\begin{aligned}
& >>\operatorname{var} A=1000 ; \text { ans } \operatorname{var} A=1000 \\
& >>\operatorname{varB}=\left[\begin{array}{lll}
45 & 23545
\end{array}\right] ; \text { ans } \operatorname{var} \mathrm{B}=4523545 \\
& \text { >> } \operatorname{varC}=\text { 'test variabel' ; } \operatorname{varC}=\text { test variable }
\end{aligned}
$$

Penamaan variabel pada matlab bersifat caseSensitif karena itu perlu diperhatikan penggunaan huruf besar dan kecil pada penamaan variabel. Apabila terdapat variabel lama dengan nama yang sama maka matlab secara otomatis akan me-replace variabel lama tersebut dengan variabel baru yang dibuat user.

\section{Operator}

Beberapa penggunaan operator aritmatika antara dua operand (A dan B) ditunjukkan pada table berikut ini 
Tabel 1: Penggunaan Operator Aritmatika antara dua Operand (A dan B).

\begin{tabular}{|c|c|c|c|}
\hline Operasi & $\begin{array}{c}\text { Bentuk Al- } \\
\text { jabar }\end{array}$ & $\begin{array}{c}\text { Bentuk } \\
\text { Matlab }\end{array}$ & Contoh \\
\hline Perkalian & $\mathrm{AxB}$ & $\mathrm{A}^{*} \mathrm{~B}$ & $5^{*} 3$ \\
\hline Pembagian & $\mathrm{A}: \mathrm{B}$ & $\mathrm{A} / \mathrm{B}$ & $8 / 2$ \\
\hline Penambahan & $\mathrm{A}+\mathrm{B}$ & $\mathrm{A}+\mathrm{B}$ & $6+7$ \\
\hline Pengurangan & $\mathrm{A}-\mathrm{B}$ & $\mathrm{A}-\mathrm{B}$ & $9-4$ \\
\hline Eksponensial & $\mathrm{A}^{\mathrm{B}}$ & $\mathrm{A}^{\wedge} \mathrm{B}$ & $2^{\wedge} 3$ \\
\hline
\end{tabular}

\section{Fungsi Matematika lainnya}

Beberapa fungsi matematika lainnya yang dapat kita gunakan untuk operasi matematika antara lain sebagai berikut:

- $\operatorname{abs}(\mathrm{x})$ : fungsi untuk menghasilkan nilai absolut dari $\mathrm{x}$

- $\operatorname{sign}(x)$ : fungsi untuk menghasilkan nilai -1 jika $x<0,0$ jika $\mathrm{x}=0$ dan 1 jika $\mathrm{x}>1$

- $\exp (\mathrm{x})$ : untuk menghasilkan nilai eksponensian natural, ex

- $\log (\mathrm{x})$ : untuk menghasilkan nilai logaritma natural $\mathrm{x}, \ln x$

- $\log 10(x)$ : untuk menghasilkan nilai logaritma dengan basis $10, x 10 \log$

- $\operatorname{sqrt}(\mathrm{x})$ : untuk menghasilkan akar dari nilai $\mathrm{x}, \mathrm{x}$

- $\operatorname{rem}(x, y)$ : untuk menghasilkan nilai modulus (sisa pembagian) $x$ terhadap $y$

\section{APLIKASI MATLAB DALAM ALJABAR LINIER}

Dewasa ini proses pembelajaran matematika sudah lebih maju, yakni dengan menggunakan Matlab sebagai alat komunikasi yang dapat membantu guru dalam pembelajaran matematika. Matlab dikembangkan sebagai bahasa pemrograman sekaligus alat visualisasi yang menawarkan banyak kemampuan untuk menyelesaikan berbagai kasus yang berhubungan langsung dengan matematika. Dalam pembelajaran matematika, Matlab dapat membantu guru dan peserta didik untuk mengkomunikasikan konsep matematika. Manurut Caesarendra, W dan Ariyanto,M (2011 : 121) bahwa beberapa konsep matematika 
yang dapat diuraikan dengan menggunakan Matlab diantaranya meliputi ; matriks, vector, aljabar linier, statistic, polynomial, analisis fungsi, pencocokan kurva, interpolasi, limit, differensial, integral, transformasi Laplace, transformasi Fourier, Persamaan differensial biasa, (Ordinary Differential Equation, ODE) serta, persamaan differensial parsial (Partial Differential Equation (PDE).

Selanjutnya, akan ditunjukkan konsep matematika pada aljabar linier yang dapat dikomunikasi dengan menggunakan Matlab. Uraian ini bersifat sebagai contoh penggunaan Matlab dan berupaya memberikan motivasi Mahasiswa untuk dapat mengembangkan kemampuannya terhadap penggunaan software Matlab.

\section{MATRIKS}

Terdapat tiga jenis format data di MATLAB, yaitu skalar, vektor, dan matriks.

- Skalar, ialah suatu bilangan tunggal

- Vektor, ialah sekelompok bilangan yang tersusun 1-dimensi. Dalam MATLAB biasanya disajikan sebagai vektor-baris atau vektor-kolom

- Matriks, ialah sekelompok bilangan yang tersusun dalam segi-empat 2-dimensi. Di dalam MATLAB, matriks didefinisikan dengan jumlah baris dan kolomnya. Di MATLAB terdapat pula matriks berdimensi 3, 4, atau lebih, namun dalam buku ini kita batasi hingga 2-dimensi saja.

Sebenarnya, semua data bisa dinyatakan sebagai matriks. Skalar bisa dianggap sebagai matriks satu baris - satu kolom (matriks $1 \times 1$ ), dan vektor bisa dianggap sebagai matriks 1-dimensi: satu baris $-\mathrm{n}$ kolom, atau $\mathrm{n}$ baris -1 kolom (matriks $1 \times \mathrm{n}$ atau $n \times 1$ ). Semua perhitungan di MATLAB dilakukan dengan matriks, sehingga disebut MATrix LABoratory.

Matriks didefinisikan dengan kurung siku ( [ ] ) dan biasanya dituliskan baris-per-baris. Tanda koma (,) digunakan untuk memisahkan kolom, dan titik-koma (;) untuk memisahkan baris. Kita juga bisa menggunakan spasi untuk memisahkan kolom 
dan menekan Enter ke baris baru untuk memisahkan baris.

Perhatikan cara mendefinisikan skalar dengan ataupun tanpa kurung siku.

$$
\begin{array}{ll}
\text { > skalar } 1=3.1415 & \text { skalar } 1=3.1415 \\
\text { > s skalar2 }=[2.71828] & \text { skalar2 }=2.7183
\end{array}
$$

\section{OPERASI MATRIKS}

\section{Himpunan Persamaan Linier}

Semula MATLAB diciptakan untuk menyederhanakan komputasi matriks dan aljabar linier yang terdapat di berbagai aplikasi.

$$
\left[\begin{array}{lll}
1 & 2 & 3 \\
4 & 5 & 6 \\
7 & 8 & 0
\end{array}\right] \cdot\left[\begin{array}{l}
x 1 \\
x 2 \\
x 3
\end{array}\right]=\left[\begin{array}{l}
366 \\
804 \\
351
\end{array}\right]
$$

Contoh : A. $x=b$

Dalam MATLAB perkalian matriks dilambangkan asterik $\left.{ }^{*}\right)$. Jika terdapat suatu penyelesaian, maka juga terdapat beberapa metode untuk menyelesaikannya, seperti eliminasi gaus, faktorisasi $\mathrm{LU}$, atau penggunaan langsung dari $\mathrm{A}^{-1}$. secara analisis, penyelesaian ditulis sebagai $x=A^{-1} \cdot b$.

Untuk menyelesaikan masalah tersebut di atas diperlukan cara untuk memasukkan A dan b.

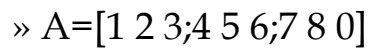

$$
\begin{aligned}
& \mathrm{A}= \\
& 123 \\
& \begin{array}{lll}
4 & 5 & 6
\end{array} \\
& \begin{array}{lll}
7 & 8 & 0
\end{array} \\
& \text { » } \mathrm{b}=[366 ; 804 ; 351] \\
& \mathrm{b}=
\end{aligned}
$$


Jika anda mempunyai dasar aljabar linier maka sangat mudah untuk menentukan bahwa masalah mempunyai satu jawaban tunggal jika determinan matriks A tidak sama dengan nol.

$$
\begin{aligned}
& \gg \operatorname{det}(\mathrm{A}) \\
& \text { ans }=27 \\
& \text { »inv(A) } \\
& \text { ans }=-1.7778 \quad 0.8889 \quad-0.1111 \\
& \begin{array}{lll}
1.5556 & -0.7778 & 0.2222
\end{array} \\
& \begin{array}{lll}
-0.1111 & 0.2222 & -0.1111
\end{array}
\end{aligned}
$$

Penyelesaian persamaan linier tersebut dapat diselesai dengan tiga cara :

Cara I, dengan menggunakan invers matriks

$$
\text { » } \mathrm{x}=\operatorname{inv}(\mathrm{A}) * \mathrm{~b}
$$

$\mathrm{x}=$

25.0000

22.0000

99.0000

Cara II, dengan menggunakan operasi pembagian matriks

$$
\gg \mathrm{x}=\mathrm{A} \backslash \mathrm{b}
$$$$
\mathrm{x}=
$$

25.0000

22.0000

99.0000

Cara III, dengan menggunakan factorisasi lu dari hasil dari upper af lower matrik triangular , $\mathrm{A}=\mathrm{LU}$, dimana $\mathrm{X}$ diperoleh dari $\mathrm{X}=\mathrm{U}^{-1} \mathrm{~L}^{-1} \mathrm{~B}$.

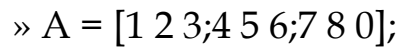

$$
\begin{aligned}
& \text { » } \mathrm{B}=[366 ; 804 ; 351] \text {; } \\
& \text { » }[\mathrm{L}, \mathrm{U}]=\operatorname{lu}(\mathrm{A}) \\
& \mathrm{L}= \\
& \begin{array}{lll}
0.1429 & 1.0000 & 0
\end{array} \\
& \begin{array}{lll}
0.5714 & 0.5000 & 1.0000
\end{array} \\
& 1.0000 \quad 0 \quad 0
\end{aligned}
$$




$$
\begin{aligned}
& \mathrm{U}= \\
& \begin{array}{lll}
7.0000 & 8.0000 & 0
\end{array} \\
& \begin{array}{lll}
0 & 0.8571 & 3.0000
\end{array} \\
& \begin{array}{lll}
0 & 0 & 4.5000
\end{array} \\
& \text { » } \mathrm{X}=\operatorname{inv}(\mathrm{U}) * \operatorname{inv}(\mathrm{L}){ }^{*} \mathrm{~B} \\
& X= \\
& 25.0000 \\
& 22.0000 \\
& 99.0000
\end{aligned}
$$

Untuk mencari nilai eigen values dan eigen vektor

$$
\begin{aligned}
& \text { » }[\mathrm{x}, \mathrm{D}]=\mathrm{eig}(\mathrm{A}) \\
& \mathrm{x}= \\
& \begin{array}{lll}
0.7471 & -0.2998 & -0.2763
\end{array} \\
& \begin{array}{lll}
-0.6582 & -0.7075 & -0.3884
\end{array} \\
& \begin{array}{lll}
0.0931 & -0.6400 & 0.8791
\end{array} \\
& \mathrm{D}= \\
& \begin{array}{lll}
-0.3884 & 0 & 0
\end{array} \\
& \begin{array}{lll}
0 & 12.1229 & 0
\end{array} \\
& \begin{array}{lll}
0 & 0 & -5.7345
\end{array} \\
& \text { » } \operatorname{eig}(\mathrm{A}) \\
& \text { ans }= \\
& -0.3884 \\
& 12.1229 \\
& -5.7345
\end{aligned}
$$

\section{Fungsi-fungsi Matriks yang umum digunakan}

$$
\begin{array}{ll}
\operatorname{det}(A) & \text { determinan } \\
d=e i g(A) & \text { Nilai eigen } \\
{[\mathrm{V}, \mathrm{D}]=\operatorname{eig}(\mathrm{A})} & \text { nilai eigen dan eigen vektor } \\
\operatorname{expm}(\mathrm{A}) & \text { pemangkatan matriks } \\
\operatorname{inv}(\mathrm{A}) & \text { invers matriks }
\end{array}
$$


Budi Cahyono

$\begin{array}{ll}\operatorname{lu}(\mathrm{A}) & \text { faktor dari eliminasi gaus } \\ \operatorname{orth}(\mathrm{A}) & \text { ortognalisasi } \\ \operatorname{pinv}(\mathrm{A}) & \text { pseudoinvers } \\ \text { poly(A) } & \text { karakteristik polynomial } \\ \text { polyeig(A1,A2,..) } & \begin{array}{l}\text { menyelesaikan masalah nilai eigen poli- } \\ \text { nomial }\end{array} \\ & \text { akar kuadrat matriks } \\ \text { sqrtm(A) } & \text { dekomposisi nilai singular } \\ \operatorname{svd}(\mathrm{A}) & \text { jumlah elemen-elemen diagonal } \\ \operatorname{trace}(\mathrm{A}) & \end{array}$

3. Matriks Khusus

Matriks dengan kegunaan umum meliputi

$$
\begin{aligned}
& \text { » zeros(3) } \\
& \text { ans }= \\
& \begin{array}{lll}
0 & 0 & 0
\end{array} \\
& \begin{array}{lll}
0 & 0 & 0
\end{array} \\
& \begin{array}{lll}
0 & 0 & 0
\end{array} \\
& \text { » ones(2,4) \% 2x4 matriks berelemen satu } \\
& \text { ans }= \\
& \begin{array}{llll}
1 & 1 & 1 & 1
\end{array} \\
& \begin{array}{llll}
1 & 1 & 1 & 1
\end{array} \\
& \text { » zeros(3)+pi } \\
& \text { ans }= \\
& 3.1416 \quad 3.1416 \quad 3.1416 \\
& 3.1416 \quad 3.1416 \quad 3.1416 \\
& 3.14163 .1416 \quad 3.1416 \\
& \text { » eye(3) \% matriks identitas } \\
& \text { ans }= \\
& \begin{array}{lll}
1 & 0 & 0
\end{array} \\
& \begin{array}{lll}
0 & 1 & 0
\end{array} \\
& \begin{array}{lll}
0 & 0 & 1
\end{array}
\end{aligned}
$$


Contoh; carilah nilai v dan gambar nilai yang diperoleh.

$\left[\begin{array}{ccc}\frac{1}{2} & -\frac{1}{2} & 0 \\ -\frac{1}{2} & \frac{1}{2}+j 0.2+\frac{-1}{j 10} & \frac{-1}{j 10} \\ 0 & -\frac{1}{j 10} & \frac{1}{10}+\frac{1}{j 10}\end{array}\right] \cdot\left[\begin{array}{l}v 1 \\ v 2 \\ v 3\end{array}\right]=\left[\begin{array}{c}-1 \\ 0 \\ 0\end{array}\right]$

kita dapat menyelesaikan dengan MATLAB dalam M-File :

$\%$ pl1.m nama proram

clear

$\mathrm{A}(1,1)=1 / 2$;

$\mathrm{A}(1,2)=-1 / 2$;

$\mathrm{A}(2,1)=-1 / 2$;

$\mathrm{A}(2,2)=1 / 2+0.2 \mathrm{j}+1 / 10 \mathrm{j}$;

$\mathrm{A}(2,3)=-1 / 10 \mathrm{j}$;

$\mathrm{A}(3,2)=-1 / 10 \mathrm{j}$;

$\mathrm{A}(3,3)=1 / 10+1 / 10 \mathrm{j}$;

$\mathrm{y}=\left[\begin{array}{lll}-1 & 0 & 0\end{array}\right]^{\prime}$;

$\%$ Penyelesaian persamaan

$\mathrm{v}=\mathrm{A} \backslash \mathrm{y}$

vmag=abs(v)

sudutv $=$ angle $(\mathrm{v})^{*} 180 /$ pi

$\%$ menggambar hasil terhadap waktu

theta $=$ linspace $\left(0,2^{*} \mathrm{pi}\right)$;

$\mathrm{v} 1=\operatorname{vmag}(1) * \cos ($ theta-sudutv $(1))$;

$\mathrm{v} 2=\operatorname{vmag}(2)^{*} \cos ($ theta-sudutv $(2))$;

$\mathrm{v} 3=\operatorname{vmag}(3)^{*} \cos ($ theta-sudutv(3));

thd $=$ theta* $180 *$ pi;

plot(thd,v1, thd, v2,thd,v3);

jika program tersebut dijalankan, hasilnya seperti dibawah ini ; 
Budi Cahyono

$$
\begin{aligned}
& \gg \mathrm{pl} 1 \\
& \mathrm{v}= \\
& -4.0000+6.0000 \mathrm{i} \\
& -2.0000+6.0000 \mathrm{i} \\
& 2.0000+4.0000 \mathrm{i} \\
& \text { vmag }=
\end{aligned}
$$

7.2111

6.3246

4.4721

sudutv $=$

123.6901

108.4349

63.4349

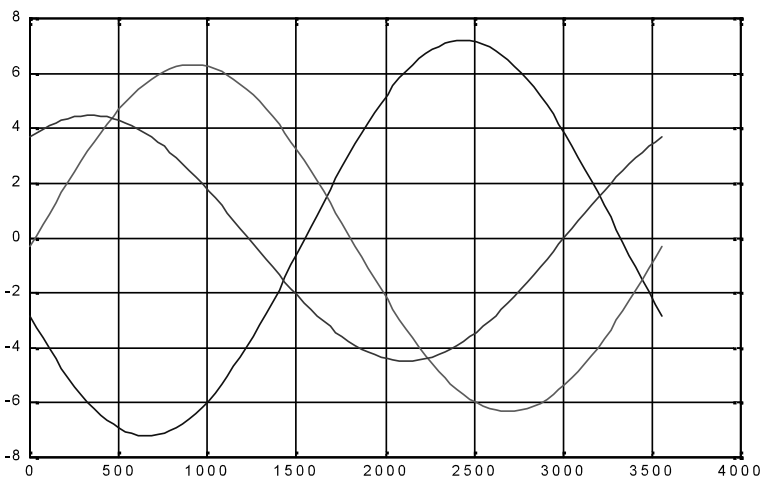

Beberapa contoh diatas jika digambar secara manual membutuhkan keterampilan tertentu, maka penggunaan MATLAB merupakan solusi pemecahannya.

\section{KESIMPULAN}

MATLAB adalah suatu paket komputasi numerik sangat kuat dan memungkinkan untuk digunakan sebagai software alternative dalam pembelajaran matematika. Diharapkan, bahwa dengan penggunaan Matlab sebagai media pembelajaran matematika mengantarkan siswa dapat belajar matematika yang lebih cepat, lebih baik dan lebih mudah, serta lebih berkualitas.

Pembelajaran matematika menggunakan MATLAB sebagai 
alat bantu komputasi tentunya tidak menjadi masalah dan akan efektif apabila dilaksanakan dalam ruang laboratorium komputer yang setiap komputernya sudah terinstal MATLAB. Selain itu waktu, ruang, dan jumlah komputer yang disediakan juga cukup memadai. Namun dalam kenyataannya tentu saja waktu, ruang, sarana dan prasarana dalam kelas atau laboratorium komputer adalah terbatas. Hal ini dapat menjadikan ketidakefektifan proses pembelajaran. Dengan adanya aplikasi ini, akan dapat mengefisiensikan biaya dan juga waktu dalam operasional pembelajaran. Selain itu, manfaat dari aplikasi ini adalah memungkinkan siswa mampu menggali lebih banyak tentang konsep numerik karena eksperimen numerik dapat dengan mudah dilakukan serta didukung dengan representasi grafik. 


\section{DAFTAR PUSTAKA}

Anton, Howard. (1984). ALJABAR LINIER. Erlangga, Bandung

Caesarendra,W.,dan Ariyanto M.,(2011) Panduan Belajar Mandiri MATLAB. Media Komputindo, Jakarta.

Firmansyah, A. (2007). Dasar-Dasar Pemrograman MATLAB. http:// ilmukomputer. org/2006/08/25/pengantar-pemrograman-berbasis-aspek/, diakses tanggal, 2 Juni 2012.

Sahid. (2004). Aplikasi Komputer dengan MATLAB. Petunjuk Praktekum MATLAB, Edisi Revisi, Laboratorium Komputer Jurusan Pendidikan Matematika, UNY. http://www.limitedbookstore.com/buku/pengantar-komputasi-numerikdengan-matlab-drs-sahid-msc.htm, diakses tanggal, 3 Juni 2013.

Sahid, (2007). Pengantar Komputasi Numerik Dengan Matlab. http://www.belbuk.com/pengantar-komputasi-numerik-dengan-matlab-p-3486.html

Hohari, K. (2010). Mengajar Matematika Secara Interaktif dengan Winplot dan Wingeom. http://bdksurabaya.kemenag. go.id/file/dokumen/wingeom.pdf, Diakses pada tanggal 3 Juni 2013. 